\title{
MACHADO'S ORGANIC SENSE: AN OUTLINE OF APPROACHES TO LIÇÃO DE BOTÂNICA
}

\section{PAUL DIXON}

Purdue University

West Lafayette, Indiana, Estados Unidos

\begin{abstract}
Machado de Assis frequently relies on controlling metaphors, which provide a unifying plan for an entire work. His play Lição de botânica is an example of this practice, where human progress is compared to the life of plants or other simpler organisms. The play contains echoes of the seventeenth-century notion of vegetable love, as seen in Robert Burton and Andrew Marvell. It follows the norms of classical comedy, which has its roots in the celebration of fertility. It illustrates the central ideas of Henri Bergson's philosophy of laughter, which opposes the organic to the mechanical. From a national perspective, it exemplifies the cultural characteristics of cordiality and preference for the jeitinho. The common denominator for all these perspectives is the rejection of rigidity in favor of organic elasticity.
\end{abstract}

Keywords: Machado de Assis; metaphor; theater; comedy; laughter; Brazil.

\section{MACHADO E O SENTIDO ORGÂNICO:}

\section{ESBOÇO DE PERSPECTIVAS SOBRE LIÇÃO DE BOTÂNICA}

Resumo: Machado de Assis frequentemente recorre a metáforas abrangentes, que providenciam um plano unificador de um texto inteiro. Sua peça teatral Lição de botânica é um exemplo de tal prática, comparando o progresso humano à vida de uma planta ou de outro organismo simples. A peça contém ecos da noção setecentista do amor vegetal, tal como aparece em Robert Burton e Andrew Marvell. Segue as normas da comédia clássica, que tem suas raizes na celebração da fertilidade. Ilustra as ideias centrais da filosofia do riso de Henri Bergson, que opõe o orgânico ao mecânico. Desde uma perspectiva nacional, o texto exemplifica as características culturais da cordialidade e da preferência pelo jeitinho. O que todas essas perspectivas têm em comum é uma rejeição da rigidez em favor de uma elasticidade orgânica.

Palavras-chave: Machado de Assis; metáfora; teatro; comédia; riso; Brasil. 

just ornamental language. However, the figure is often much more than that - a controlling concept that can help explain an entire work. For example, in Dom Casmurro, numerous metaphors (such as the famous reference to Capitu's "olhos de ressaca") establish a comparison between an amorous relationship and a maritime voyage of discovery. The "loving equals navigating" figure creates a profoundly ironic register in which a cranky and trivial narrator tries to cast himself in a heroic mold. It also creates a network of allusions, also ironic, where the novel may be read in light of the Portuguese epic Os lusiadas and other honored maritime narratives. The short story "A igreja do diabo" suggests the problematic of human integrity with another well-known, controlling metaphor: human virtues and vices, whether within the individual or society as a whole, are "rainhas, cujo manto de veludo rematasse em franjas de algodão" (ASSIS, 1985a, p. 370). This awkward combination of the noble with the vulgar may be the impetus for all kinds of reformative programs, including the devil's project of converting everyone to ignobility by pulling on the threads of the coarse cotton border. But because of the "eterna contradição humana" (ASSIS, 1985a, p. 374) the best (or worst) one can ever expect is "capas de algodão [com] franjas de seda" (ASSIS, 1985a, p. 374). The metaphor of the incompatible fabrics not only acts as a design for all that happens in the story, but it can also be thought of as a map of Machado's world view, where nothing is truly complete, and where opposing forces seem always to be contending for the same space.

In this essay I will address another of these broadly influential metaphors - that of botanical or organic progression, as seen in the one-act comedy, Lição de botânica (1905). I will attempt to show that with this poetic figure, Machado not only communicates an engaging story of overcoming romantic obstacles, that he also ties into a tradition of thinking about "vegetative" affection that goes back to the seventeenth century. Furthermore, he seems to intuit the qualities that lie at the very heart of the comedic tradition in drama. I will suggest that the values of the play are concordant with one of the most important philosophical statements about humor (and indeed about human vitality in general) - Henri Bergson's Laughter. And finally, I will try to demonstrate that the play responds to and exemplifies Machado's ideas about literature and nationality, outlined in the essay "Instinto de nacionalidade" (ASSIS, 1985b). 
This essay is intended as a kind of overview of a multitude of possible perspectives regarding Machado's "botanical" sensibility as expressed in Lição de botânica (ASSIS, 1985c). Given the confines of this brief article, it is necessarily more of an outline than an in-depth analysis, perhaps a basis for further study, or a suggestion for application of certain ideas to other texts by the Brazilian author. I wish to show that Machado's sense of humor, his feel for the traditions of theater, and even his ideas about nationality are interconnected - that they are compatible with various conceptual paradigms, and that all relate to an appreciation for organic pliancy as opposed to mechanical rigidity.

The action of the play is simple. Leonor and her two nieces - Cecília and Helena (a widow) - live together in the same household. A neighbor, the Swedish botanist Barão Sigismundo de Kernoberg, requests a meeting with D. Leonor. Cecília has been seeing the botanist's nephew, Henrique, and the ladies' first guess is that the Swedish gentleman wants to ask for Cecília's hand in marriage on behalf of the young man. But the women are mistaken; instead, the professor requests that there be no further meetings between Cecília and Henrique. His nephew, he explains, is destined to follow his same vocation, and for several generations in the family, a succession of botanists (all uncles and nephews) have wisely chosen celibacy, or rather, to be married to their research. The demands of serious scientific inquiry are such that no other devotion, such as family, can be considered. At first Cecília is crestfallen, but by feigning an interest in botany and an openness to lessons from the professor, Helena begins to exercise her feminine charms upon the man. Before long, Kernoberg has decided that perhaps a botanist can be married after all. He consents to the marriage of Cecília and Henrique, and even begs to have the same privilege with Helena.

When at the very end of the play, D. Leonor expresses astonishment at the change in the neighbor's strict resolution, Helena declares: "Não se admire tanto, titia; tudo isto é botânica aplicada" (ASSIS, 1985c, p. 1.187). This closing line makes explicit the metaphor that has been operating throughout the play; that love is botany. The figure, I think, also involves a touch of synecdoche in the following sense: botany is just one of many natural sciences, and all those sciences express certain laws of attraction necessary to assure the continuation of the species through reproduction. Botany, then, is a part standing for a whole. Not themselves being plants, humans are not subject to botanic precepts when it 
comes to their pairing habits. However, because botany is one of a group of sciences that share similar concepts, there is, figuratively speaking, a kind of botany that operates among people.

Lição de botânica, like so many of Machado's texts, is a study in contrasting characters or attitudes. The Swedish scientist presents one approach to the world, while the neighboring women present their own contrasting way of perceiving and acting. Interestingly, in their approach to the novelties and challenges of life, the women are much more "botanical" than the well-trained man. Initially, the title of the play seems to refer to the Swede's offer to provide "lições de botânica" to Helena once he learns of her mental aptitude and her interest in the subject. But by the end of the play, spectators realize that it is the women (and Helena in particular) who have a superior (though intuitive) knowledge of the laws of nature, and it is therefore they who give a "lição de botânica" to the doctor himself.

\section{Vegetable Love}

There would seem to be at least a faint echo of some earlier "philosophies" or "sciences" connecting botany and love. In The Anatomy of Melancholy, with which Machado is presumed to have had some acquaintance, ${ }^{1}$ Robert Burton (1977) conducts a taxonomy of love, citing many earlier treatises. From Leo the Hebrew's Dialogs of Love (dialog 2) he reports that love can be divided into natural, sensible and rational categories. Natural love is the simple attraction that elements seem to have for each other, and may even have been seen in inanimate objects, such as loadstone and iron (BURTON, 1977, p. 15). Sensible love is proper to animals, and is sexual attraction directed towards reproduction (BURTON, 1977, p. 16). Rational love belongs only to humans, and is love for truth, beauty or virtue (BURTON, 1977, p. 16). Burton (1977, p. 15) describes natural love as "vegetative": "'Tis more eminent in plants, herbs, and is especially observed in vegetals; as between the vine and elm a great sympathy; between the vine and the cabbage, between the vine and the olive." In this paradigm, then, natural love seems to involve a mere attraction among types,

\footnotetext{
${ }^{1}$ See, for example, Jackson (2015, p. 92).
} 
often of different species. It would appear to be a matter of symbiotic relationships, where sharing the same space proves beneficial to all parties.

In the play, we find a clear demarcation of difference between one house and another. In one space there are Brazilian women, who have no serious acquaintance with science. In the other, a Swedish man dedicated to botany, and his nephew. When Leonor, the "senhora" of the house receives word that the Barão wishes to speak with her, the immediate sense of otherness and even potential revulsion is quite clear: "Botânico e sueco: duas razões para ser gravemente aborrecido. Nada, não estou em casa" (ASSIS, 1985c, p. 1.171).

Helena, however, displays a different attitude. At the end of his visit, the professor inadvertently leaves behind a book; when he returns for it Helena feigns an interest in botany. This is her most direct maneuver, through which she seems simply to be willing to prolong an association with the botanist. Rather than actively trying to resolve the Swede's impediment to Cecília's courtship with Henrique, she merely seeks to develop a kind of vegetative affinity with the man, confiding in the power of a cordial relationship. When Cecília asks her, "Que devo então fazer?", she answers, "Esperar. Há tempo para tudo" (ASSIS, 1985c, p. 1.176). I consider this a very "botanical" response, in that it recognizes that the seeds of understanding or affection take time to sprout, that affections mature in their own time, and that little can be done to speed things along.

I do not know if Machado ever read Andrew Marvell. However, the English poet wrote at approximately the same time as Burton, and his masterpiece, "To His Coy Mistress", contains another suggestive reference to botanical love:

Had we but world enough and time, This coyness, lady, were no crime. We would sit down, and think which way To walk, and pass our long love's day. Thou by the Indian Ganges' side Shouldst rubies find; I by the tide Of Humber would complain. I would Love you ten years before the flood, And you should, if you please, refuse Till the conversion of the Jews. 
My vegetable love should grow

Vaster than empires and more slow;

An hundred years should go to praise

Thine eyes, and on thy forehead gaze;

Two hundred to adore each breast,

But thirty thousand to the rest;

An age at least to every part,

And the last age should show your heart.

For, lady, you deserve this state,

Nor would I love at lower rate. (MARVELL, 1983, p. 13)

These lines describe a similar version of "vegetable love," a love of patient propinquity. Marvell and his contemporaries, unaware of the true functions of stamen and pistil, believed that plant reproduction was non-sexual (SWANN, 2012, p. 140). The two parties in the poem might take their sweet time to "sit down" together, to plan which way they will walk through "love's long day." The man who speaks imagines taking decades to enjoy his partner's company, and centuries to admire her eyes and other physical attributes. He takes special care to point how "slow" the progress of "vegetable love" is, and what patience it must require.

Of course, we know that the remainder of the poem points out that human beings are animals, and not vegetables, and that the course of their lives follows a different schedule than that of plants. The famous carpe diem poem claims that all humans are chased by the inexorable chariot of time, and that they therefore must engage in what Burton (or Leo the Hebrew) would call "sensible love" while there is still time. Marvell seems to suggest that humans may start out enjoying a kind of patient, botanical affection, but that by their very nature they are bound to progress from this calm and sedentary beginning to a more dynamic plane, to animal love, where they are more moving and more moved, and willing to engage in the race against time:

And tear our pleasures with rough strife

Through the iron gates of life:

Thus, though we cannot make our sun

Stand still, yet we will make him run. (MARVELL, 1983, p. 13) 
Helena seems intuitively to understand that the kind of affection culminating in marriage is likely to begin as a more "botanical" sympathy and sociability. A correlative of this understanding is that slowing down the beginning is apt to increase the sense of urgency for the end. D. Leonor, in Machado's play, apparently has an appreciation for the power of delaying. When the professor asks her for permission to provide lessons in plant science to Helena, she replies, "Nesse caso, deixe-me refletir." The Barão then asks, "Cinco minutos?", and Leonor answers, "Vinte e quatro horas" (ASSIS, 1985c, p. 1.181). This small dialog suggests that Helena's guardian understands the strategic importance of not assenting to the man's desires too soon, because obliging a bit of patience may not only test his resolve but also build that desire. When at the end of the play, Sigismundo declares his intention to propose marriage to Helena. She answers with the imperative: "Dê-me três meses de reflexão." When the Barão complains that "Três meses é a eternidade," Helena replies, "Uma eternidade de noventa dias" (ASSIS, 1985c, p. 1.187). In Machado's play "botânica" takes on the sense of a slow and gradual approach to affection that begins with mere social interaction and, through encouraged anticipation, calmly and freely builds desire and passion. And Lição de botânica suggests that women may naturally have more power to practice this amorous science than men.

\section{Seeds of Comedy}

Lição de botânica has a comfortable relationship with the classical traditions of comedy. And it may be helpful to remember that the origins of Greek drama are related to fertility rituals, the celebrations and invocations of the cyclical rhythms of decaying and flourishing botanical and animal nature. Northrop Frye (1957, p. 163) - for whom all of literary expression is derived from the yearly process of decline and rebirth, the resurgence of vegetable and animal vitality following the dormancy of winter - associates comedy with the "mythos of spring": "What normally happens is that a young man wants a young woman, that his desire is resisted by some opposition, usually paternal, and that near the end of the play some twist in the plot enables the hero to have his will." Although the young man in Machado's play never appears, Henrique is present enough. However, the young woman, Cecília, is the primary agent of desire. The 
obstacle is embodied in an uncle rather than a father. But these are only minor variations in a play that follows the overall classical formula with great fidelity. Consulting the Tratatus Coislinianus, an ancient commentary probably based on Aristotle, Frye (1957, p. 172-173) speaks of the two main groups of characters constituting comedy. In the Brazilian play the alazon group, representing the fixated obstacle to realization of desire, is embodied in the Barão, who displays all the obsession, rigidity and gullibility identified by Frye as typical characteristics. The eiron group, comprising the characters whose desires are suffering from oppression, is represented by Cecília, the young candidate for marriage, Henrique, her offstage suitor, Helena who initially functions as "the type entrusted with hatching the schemes which bring about the hero's victory" (FRYE, 1957, p. 173) and who also becomes a candidate for marriage, and D. Leonor, who simply wants the best for her nieces.

The "twist in the plot" identified by Frye (1957, p. 174) is typically an act of deceit, often involving some form of disguise. In Lição de botânica, the trick could hardly be simpler. Helena "disguises" herself as a person with a sincere interest in botany in order to encourage the Barão to give her private lessons in the subject. The rest of her project is hardly subversive; she will simply let nature take its course when a man is put into the company of an attractive and interested woman.

According to tradition, comedies normally end with a party (most typically a marriage), which represents the triumph of vital energies, the birth of a free new generation (FRYE, 1957, p. 170). In Machado's play, the marriage (probably a double one) is foreseen rather than realized, but its significance and dramatic function are the same. The forces of authoritative oppression have been overcome, and the future looks green and bounteous.

\section{The Organic vs. the Mechanical}

Machado's affinity for a botanical metaphor in the depiction of human affairs offers a correspondence or sympathy with the philosophy of a contemporary, Henri Bergson (2014), in his well-known views on humor. In Laughter: An Essay on the Meaning of the Comic, Bergson imagines the comic as a ludic human impulse rather than as a dramatic tradition. His condition for that comic impulse is the perception of "Something mechanical encrusted upon 
the living" (BERGSON, 2014, p. 37). Bergson's philosophy is not specifically focused on plant life, but it touches upon general principles of evolutionary survival that apply to plants and animals alike. His representation of the demands of "living" applies most explicitly to humans in society, but his assertions might apply equally well to other forms of life. He asserts, "What life and society require of each of us is a constantly alert attention that discerns the outlines of the present situation, together with a certain elasticity of mind and body to enable us to adapt ourselves in consequence" (BERGSON, 2014, p. 18). This supple sensitivity to circumstances is repeatedly referred to as elasticity. Viable organisms have the ability to bend, to conform to changing conditions as they emerge. And society will be suspicious "of all inelasticity of character or mind or even of body" (BERGSON, 2014, p. 19) because it is inimical to the adaptable sensitivity that assures the continuation of life. An example of organic elasticity: when confronted with significant cold or lack of water, plants go dormant, preserving energy for a time when conditions will be more favorable for growth.

The comic character is one who is inattentive or forgetful when it comes to this need for elastic adaptation. Bergson offers the example of an absentminded individual who fails to notice that the location of a chair has been changed. The person sits according to habit, but smashes to the floor because the furniture, presumed to be there, is absent: "What was wanted was to check the movement or deflect it. He did nothing of the sort, but continued like a machine in the same straight line" (BERGSON, 2014, p. 9-10). Bergson suggests that laughter is a kind of defense, an impulse of resistance against mechanical, inflexible actions or attitudes that are unfavorable to the continuation of life itself.

In the play, Barão Sigismundo is the obvious comic character, a depiction of mechanical thoughts and actions. His very first speech suggests a kind of robotic obsession:

Sou o barão Sigismundo de Kernoberg, seu vizinho, botânico de vocação, profissão e tradição, membro da Academia de Estocolmo, e comissionado pelo governo da Suécia para estudar a flora da América do Sul. V. Exa. dispensa a minha biografia? (D. Leonor faz um gesto afirmativo) Direi somente que o tio de meu tio foi botânico, meu tio botânico, eu botânico, e meu sobrinho há de ser botânico. Todos somos botânicos de tios a 
sobrinhos. Isto de algum modo explica minha vinda a esta casa. (ASSIS, 1985c, p. 1.173-1.174)

The repetitive insistence of "botânico de vocação, profissão e tradição" pounds home its point like a jack hammer. The generational iteration of the botanical profession, passing from uncle to nephew over and over, has a machine-like predictability. The apparent need to recite his list of credentials to a next-door neighbor, the out-of-place formality of "V. Exa." and the request for permission to go no further in the details of introduction - all of these suggest a rigidity of attitude and a failure to adapt one's language to a less formal circumstance.

The logic behind the professor's visit - a request that further interactions among niece and nephew be prohibited because of a perception of the absolute incompatibility between a life of science and the married state - is the attitude of one who must, as Bergson (2014, p. 9-10) said, "continue like a machine in a straight line". The lack of elasticity of the scientist's position is more than evident. The non-viability of this inflexible attitude is not a mere poetic suggestion; if one of the botanists were to be an only child, the generational succession of scientists would come to an inexorable end!

On the other hand, the women of the neighborhood embody all of the organic elasticity that Bergson sees as a necessity for survival. When Helena confirms to her aunt that Cecília is in love with the professor's nephew, D. Leonor recognizes the need for flexibility, to "ter paciência, sujeit[ar-se] às circunstâncias" (ASSIS, 1985c, p. 1.176). However, the adaptation she seems to be considering is for Cecília to forget about Henrique. Leonor believes that "não hão de faltar casamentos a Cecília" (ASSIS, 1985c, p. 1.176). But Helena proposes another kind of elasticity: "Reconciliemo-nos com o barão" (ASSIS, 1985c, p. 1.176).

Helena's adaptation has a decidedly improvisatory quality. It all begins when she notices that the professor has left behind the book he was carrying. She wonders, "Quem sabe se este livro pode salvar tudo? (depois de um instante de reflexão) Sim, é possível. Tratará de botânica?" (ASSIS, 1985c, p. 1.177). With creative adeptness, she learns a few bits of vocabulary from Cecília and invents the charade of an interest in botany. The baron proposes private lessons, and she hesitates, "Não sei se deva aceitar" (ASSIS, 1985c, p. 1.178), seeming to understand intuitively the power of a semi-refusal in reinforcing a suitor's 
resolve. Similarly, D. Leonor does not immediately consent when the scientist asks her permission to provide the lessons. She asks for time to consider the matter. "Cinco minutos?", asks the Barão. "Vinte e quatro horas," replies the aunt (ASSIS, 1985c, p. 1.181). Leonor is also capable of strategic adaptation, using delay as a means of increasing a male's interest. Both Helena and Leonor comprehend the means and ends of the project; in fact, Leonor uses a botanical metaphor to describe the undertaking: "Valia a pena cultivá-lo de perto" (ASSIS, 1985c, p. 1.181).

Even before Helena receives her first lesson, she subtly creates her own teaching moment, suggesting that instead of interfering with the pursuit of science, "A esposa fortifica a alma do sábio" (ASSIS, 1985c, p. 1.180), by accompanying and encouraging his research, telling others of his efforts, and rewarding him with her best domestic approbation when he achieves a goal. After the Barão comes back and says he is having second thoughts about the lessons, because of the limitations of his own knowledge (likely a bit of false modesty), of his own brusque and despotic nature, and Helena's tender age. Instead of begging, Helena boldly accepts his doubts and releases him from the commitment. She also frankly states that he is "caprichoso e incoerente" (ASSIS, $1985 \mathrm{c}$, p. 1.183). These are unexpected responses, and seem to leave the Swede off-balance. And then Helena says she will have to continue studying botany on her own, probably having to "queimar os olhos nos livros." This prompts the professor to respond, "Oh! seria estragar as mais belas flores do mundo!" (ASSIS, $1985 \mathrm{c}$, p. 1.184). It is easy to see where things are headed, and before long the man is expressing "A esperança de que... a esperança de..." (ASSIS, 1985c, p. 1.185). Helena also sees where thing are going, but plays with the timidity of his proposal by guessing that he is trying to refer to the hope of giving her botany lessons. The Barão keeps trying to say the words until, at the very end, Helena decides to help him out: "O que o Sr. barão deseja é a minha mão" (ASSIS, 1985c, p. 1.186).

From all this we see that Helena is the polar opposite of the Swedish man of science. Where he is rigid, formal, mechanical and sometimes even paralyzed, she is lithe, sensitive, responsive to new opportunities, and able to change courses at a second's notice. Helena is the very incarnation of Bergson's notion of elasticity. 


\section{Elasticity and Nationality}

When D. Leonor learns that Helena is planning to receive botany lessons, and that Cecília is very much in favor of that idea, she protests, "Esta casa está ficando muito sueca; voltemos a ser brasileiras" (ASSIS, 1985c, p. 1.182). It should come as no surprise, then, that a discourse on nationality should be considered as a subplot of the play. The play involves not just opposing characters or personalities, but also opposing nationalities. It is hard not to read the work, at least to some degree, as a comment on northern cultural dispositions in relation to southern ones, and as at least an indirect statement about what constitutes the Brazilian temperament.

In the essay "Instinto de nacionalidade," Machado appealed for a less superficial vocabulary when it came to Brazilian authors' attempts to represent their country through literature. Characteristics like Brazilian flora and fauna, the peculiarities of regional speech, and folk customs, while not to be forbidden as indicators of Brazil, should also not be considered sufficient. Indigenous characters and regional types are also welcome, but not in themselves enough to establish a national character for a given work. Machado's (1985b, p. 804) prescription for an authentic Brazilian character has deeper characteristics in mind: "O que se deve exigir do escritor, antes de tudo, é certo sentimento íntimo, que o torne homem do seu tempo e do seu país, ainda quando trate de assuntos remotos no tempo e no espaço."

In Lição de botânica we find a model for what can be understood as "certo sentimento íntimo," suggesting a more authentic national characterization. While we can affirm this in the case of Brazil and Brazilians, we can certainly not say it about Sweden. It can be agreed that the treatment of the Barão is about as stereotypical as it comes. The botanist is a reductive, exaggerated representation of a fastidious rigor that can be identified as a tendency in many northern cultures. Such a gross caricature may be excused, perhaps, because the play is very short, because as a Brazilian the playwright cannot be expected to know everything about Swedes, and because he was trying to be funny. Stereotype and humor go hand in hand.

When it comes to Helena, the main Brazilian character, it is indeed

possible to identify forms of thinking and acting that are consistent with widely discussed traits of the Brazilian "character." Helena, in a sense, must try to 
negotiate with the "other" from a somewhat disadvantaged position. She is a woman and, therefore, at the time is assumed to have an inferior status. In fact, she has not enjoyed the same educational advantages as the man, who presumably has an advanced college degree and is a widely recognized expert on an academic topic. He knows everything about botany; she knows almost nothing. A baron, he apparently is of a highly privileged class, while Helena appears to have no particular distinction on the social ladder. If she must live with her aunt, she has apparently not inherited a great deal of money from her deceased husband. What, then, are the resources that can help her in this asymmetrical interaction? In Raizes do Brasil, Sérgio Buarque de Hollanda (1995) identifies conviviality as an important trait of the Brazilian personality. He speaks of o homem cordial (HOLANDA, 1995, p. 147), and shows how a facility for social relationships gives Brazilians a kind of capital that can be applied to life's opportunities and challenges. Friends and relatives can be counted on. Productive conversations mean that people can be persuaded. Favors can be done for others, which builds a sort of credit for future eventualities, so that favors can be called in. I propose that Helena embodies a mulher cordial, and that in that sense she is a kind of ideal Brazilian. When presented with the obstacle to Cecilia's happiness with Enrique, her first impulse is to get to know the other: "Reconciliemo-nos com o barão" (ASSIS, 1985c, p. 1.176). While D. Leonor is inclined to close her door to Henrique and his uncle, Helena seems already to have some acquaintance with Henrique, and appreciates that he is "um perfeito cavalheiro" (ASSIS, 1985c, p. 1.175), worthy of Cecília. Her initial approach is based on the very Brazilian premise that it is always best to get to know the person one is dealing with. This impulse might be connected to the idea of vegetable love discussed earlier. Associations are the starting point, which lead to understanding, sometimes to affinities, and sometimes even to love. It is possible to assume that Helena sets out to make the Barão fall in love with her. But is that really probable, in view of the unsympathetic initial portrayal of the Swede? It seems more likely that she simply wants to have the chance to get to know him, and to have him get to know her, hoping for an understanding that a woman's love is not fatal to scientific endeavors. 
Another much discussed Brazilian trait is a talent for the jeitinho, ${ }^{2}$ the lateral maneuver that attempts to solve problems through indirect means, and often through bending the usual rules. Helena's comportment in the play can appropriately be called a jeitinho. The central problem is the impediment of the courtship between Cecília and Henrique, because of the botanist's belief that science and marriage are incongruous. The business of Helena's "interest" in botany constitutes a lateral diversion, in that it takes attention away from the immediate threat to the happiness of Henrique and Cecília. Helena's feigned fascination with plants, improvised at a moment's notice, is a sly ruse, wholly compatible with the storied Brazilian practice. Whether or not she fully intends to make the professor fall in love with her, that is what Helena accomplishes in the end. If he now desires to be a married man, the scientist can hardly continue to prohibit his nephew from pursuing the same state. In keeping with the typical pattern of the jeitinho, then, the play's main female character solves the problem of Cecília's frustrated courtship in an oblique, indirect way. If the women of the play provide applied botany instruction to the man, the lesson would seem to be a lesson in Brazilian culture as well.

We cannot fail to detect considerable overlap between the jeitinho of Brazilian culture and the twist described by Northrop Frye in the classical configuration of comedy. The play would seem to be a convincing example of how a work can be quite Brazilian and quite universal at the same time.

In fact there is a common thread for all the perspectives that have here been brought to bear on Machado's play. Whether we appreciate the drama in light of its controlling botanical metaphor, its participation in the aged traditions of comedy, its consonance with Bergson's theories of laughter, or its roots in Brazilian culture, the play proposes that dogmatic directionality or rigidity, which leads to exclusion, must be overcome by fertile, supple, organic, openness. Therein lies the ultimate botanical lesson.

\section{References}

ASSIS, Machado de. A igreja do diabo. In: Obra completa. Rio de Janeiro: Nova Aguilar, 1985a. v. 2

\footnotetext{
${ }^{2}$ For example, see Damatta (2000, p. 95-105).
} 
Machado de Assis em Linha - Universidade de São Paulo

http://machadodeassis.fflch.usp.br

Instinto de nacionalidade. In: Obra completa. Rio de Janeiro: Nova Aguilar, 1985b. v. 3.

Lição de botânica. In: Obra completa. Rio de Janeiro: Nova Aguilar, 1985c. v. 2.

BERGSON, Henri. Laughter: An Essay on the Meaning of the Comic. Mansfield Centre, Connecticut: Martino, 2014.

BURTON, Robert. The Anatomy of Melancholy. Ed. Holbrook Jackson. New York: Vintage, 1977.

DAMATTA, Roberto. O que faz o brasil, Brasil? Rio de Janeiro: Rocco, 2000.

FRYE, Northrop. Anatomy of Criticism: Four Essays. Princeton, New Jersey: Princeton University Press, 1957.

HOLANDA, Sérgio Buarque de. Raízes do Brasil. 26th ed. São Paulo: Companhia das Letras, 1995.

JACKSON, K. David. Machado de Assis: a Literary Life. New Haven, Connecticut: Yale University Press, 2015.

MARVELL, Andrew. Complete poems. Ed. Elizabeth Story Donno. London: Penguin, 1983.

SWANN, Marjorie. Vegetable Love: Botany and Sexuality in Seventeenth-century England. In: FEERICK, J. E.; NARDIZZI, V. (Eds.). The Indistinct Human in Renaissance Literature: Early Modern Cultural Studies. New York: Palgrave Macmillan, 2012. p. 139-158.

PAUL DIXON (PhD University of North Carolina) has taught Latin American Literature at Purdue University (Indiana, USA) since 1981. He is the author of numerous studies on Machado de Assis, including the following books: Retired Dreams: Dom Casmurro, Myth and Modernity (Purdue University Press, 1989), Os contos de Machado de Assis: mais do que sonha a filosofia (Movimento, 1992), O chocalho de Brás Cubas: uma leitura das Memórias póstumas (EDUSP; Nankin, 2009) e Por linhas tortas: uma leitura de Quincas Borba (EDUSP; Nankin, no prelo). Dixon has taught as a visiting professor at the Federal University of Rio Grande do Sul, the Catholic University of Rio Grande do Sul, Brigham Young University and Feevale University. E-mail: tudobem@purdue.edu

Recebido: 19.11 .2018

Aprovado: 24.01.2019 